研

究

\title{
高速度工具鋼と低合金鋼の焼結接合材の組織と強度
}

\author{
加藤 寛敬出 1 , 䉆田 一夫兽田 裕二牥3 \\ 中1 福井工業高等専門学校機械工学科, $=916-8507$ 鯖江市下司町.

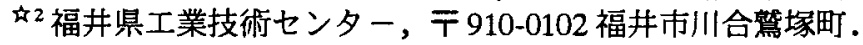 \\ 的三菱製鋼散，广 969-3471 福島県河沼郡河東町大字広田字六丁.
}

\section{Microstructure and Strength of Sinter-Bonding of High Speed Steel and Low Alloy Steel}

\author{
Hirotaka Kato ${ }^{21}$, Kazuo Washida ${ }^{\text {th }}$ and Yuji Soda 3 \\ '1 1 Dept. Mech. Eng., Fukui National College of Technology, Geshi-cho, Sabae 916-8507. \\ ${ }^{2}$ Industrial Technology Center of Fukui Prefecture, Kawaiwashizuka-cho, Fukui 910-0102. \\ ${ }^{3}$ Mitsubishi Steel Mgf. Co.,LTD., Hirota, Kawahigashi-machi, Kawanuma-gun, Fukushima 969-3471.
}

Received December 13, 2001

\section{SYNOPSIS}

High speed steel and low alloy steel were bonded by powder sintering processes in order to investigate the effects of carbon content of high speed steel and sintering temperature on the bonding behavior. Two type bonding methods were studied, i.e. the process $\mathbf{A}$ in which high speed steel and low alloy steel green compacts were bonded by sintering without a bonding pressure, and the process $\mathrm{B}$ in which two-layer powders of the steels compacted and then sintered. The density, microstructure and four-point bending strength of the bonded specimens were examined. It was found in the process $\mathbf{A}$ that the two steels were not bonded at lower sintering temperature than the temperature (Ts) at which the relative density of sintered high speed steel reached $98 \%$, and that bonded specimens showed the highest bending strength at higher sintering temperature than the Ts by $20 \mathrm{~K}$. In the process $\mathrm{B}$, there was no significant influence of carbon content and sintering temperature on the bending strength, and the maximum bending strength was lower than that of the bonded specimens by the process A. This was considered to be due to both the micro-pores produced at the interface and the residual tensile stress of the bonded specimens.

KEY WORDS

sinter-bonding, high speed steel, low alloy steel, microstructure, bending strength

\section{1 緒言}

粉末の焼結現象を利用して異種材を接合させる焼結接合と して，材質の異なる粉末を別々に圧縮成形しそれを組立てて 焼結する圧粉体同志接合と，同一金型内で材質の異なる粉末 を2層に充填し圧縮成形した後焼結により接合させる 2 層成 形接合がある1,2).これらの接合方法は，一般に接合圧力を付 与せずに接合しニヤネットシェイプに製造できるため,生産 性がよいという特徵がある。しかしながら，接合強度を十分 に把握する必要があると思われる．とくに，耐摩耗材料であ る高速度工具鋼と構造材料である低合金鋼の焼結接合は, 工 業的に重要であるにもかかわらず3,4，これらの接合強度に関 する研究らはほとんどなされていない。

そこで本研究では，高速度工具鋼と低合金鋼の圧粉体同志 接合と2層成形接合に着目しこれらの接合材の接合組織と4点 曲げ強度を評価した．また，高速度工具鋼の炭素量と焼結温 度を変化させて，焼結密度や焼結時に発生する液相量が接合
組織や曲げ強度に及ぼす影響について検討した。

\section{2 試料および実験方法}

本実験で使用した鋼粉は，水アトマイズ法で製造された， 神戸製鋼所製の低合金鋼粉アトメル 4600 (粒度: -80 mesh) と 三菱製鋼製の高速度工具鋼粉 M2 (粒度 : $-100 \mathrm{mesh}$ )である. Table 1に，その鋼粉の化学成分を示す.また，炭素源として Lonza製の黒鉛粉 F10 (平均粒径: $6 \mu \mathrm{m}$ ) を用いた。接合材の低

Table 1 Chemical composition of steel powder.

\begin{tabular}{|l|c|c|c|c|c|c|}
\hline \multirow{2}{*}{ powder } & \multicolumn{5}{|c|}{ mass\% of alloying element } \\
\cline { 2 - 7 } & $\mathrm{C}$ & $\mathrm{Ni}$ & $\mathrm{Cr}$ & $\mathrm{Mo}$ & $\mathrm{V}$ & $\mathrm{W}$ \\
\hline $\begin{array}{l}\text { low alloy steel } \\
\text { powder (4600) }\end{array}$ & 0.001 & 1.80 & 0.47 & & & \\
\hline $\begin{array}{l}\text { high speed steel } \\
\text { powder (M2) }\end{array}$ & 0.94 & & 3.98 & 4.94 & 2.03 & 6.09 \\
\hline
\end{tabular}


合金鋼では，4600鋼粉に黒鉛粉を 0.4 mass\%添加し混合した。 高速度工具鋼では，接合材の炭素量を配合量で0.94〜 1.34 mass\% の範囲で変化させるために, 高速度工具鋼粉M2に0〜 0.4 mass $\%$ の黒鉛粉を添加した5種類の組成のものを用いた.また, 金型 潤滑剤として, ステアリン酸亜鉛粉末を 0.75 mass\%添加した.

Fig.1に，圧粉体同志接合および 2 層成形接合の成形・接合 方法を示す.粉末の圧縮成形は, $12 \times 12 \mathrm{~mm}$ の加圧面を持つ金 型を作成し，万能試験機により成形圧力 $600 \mathrm{MPa}$ で行った.圧 粉体同志接合では，幅 $12 \times 12 \mathrm{~mm}$ ，高さ $15 \mathrm{~mm}$ の低合金鋼お よび高速度工具鋼の単味圧粉体を別々に作り，それらを組立 てて焼結した.2層成形接合では, 金型内に低合金鋼粉を充填 した後，高速度工具鋼粉を充填し，幅 $12 \times 12 \mathrm{~mm}$, 高さ $30 \mathrm{~mm}$ に王縮成形し焼結した．また，接合材の強度を考察するため に, 2 層成形接合材と同じ寸法で，低合金鋼および高速度工具 鋼それそれの単味圧粉体も作製し焼結した。

焼結接合は, 真空炉により真空度䄪 $10^{-2} \mathrm{~Pa}$ で行った. 焼結 温度は $1453,1473,1493,1513,1533 \mathrm{~K}$ の 5 種類で，保持時間は それそれ $3.6 \mathrm{ks}$ とした.いずれの接合法においても高速度工具 鋼が上になるように圧粉体を設置した．焼結時の接合圧力は 無負荷で，試験片の自重のみで接合を行った. 圧粉体同志接 合では，成形時にできた圧粉体の接合面のバリを，耐水研磨 紙で取り除いてから圧粉体を組立てた. 焼結後は, 高速度工 具鋼の焼入れ硬化を図るために0.3 MPaの窒素ガスで加圧冷却 した.なお，焼き戻しなどの熱処理は実施していない。

哑結材は，アルキメテス法により焼結密度を求め，さらに 研磨した試料で光学顕微鏡組織観察およびEPMA元素分析を 行つた.また接合材の強度評価は, JIS R-1601に準拠したFig.2 に示す4点曲げ試験により行った.試験片の幅を $8 \mathrm{~mm}$ に研削し， 曲げスパンは $6 \mathrm{~mm}$ と $20 \mathrm{~mm}$ で行った。 また，曲げ試験した試験 片の破断部の断面組織観察も行った。 また，接合材の残留応 力を, X線回折法(特性 X 線 $\mathrm{Cr}-\mathrm{K} \alpha, \sin ^{2} \Psi$ 法)により測定した。

\section{3 実験結果および考察}

3.1 焼結密度および寸法収縮率

Fig.3に, 焼結温度と高速度工具鋼の炭素量が及ぼす単味焼 結材の焼結密度への影響を示す，通常の高速度工具鋼の焼結
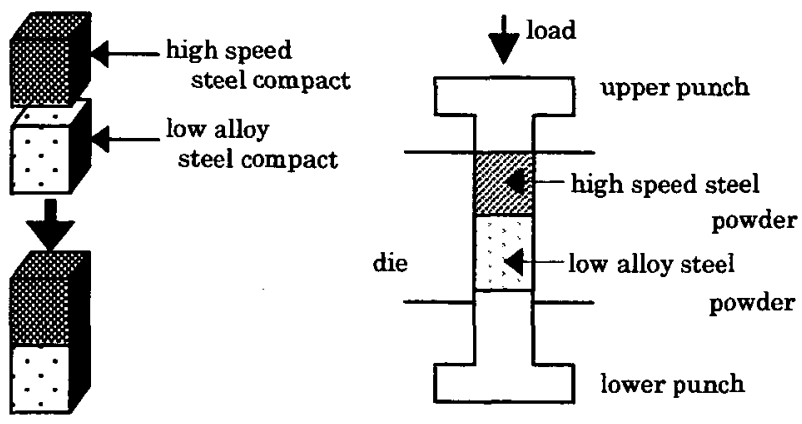

(a)

(b)

Fig.1 Bonding methods. (a) Bonding of two green compacts, (b) Bonding by two-layer compacting.
で見られるように五，それそれの炭素量においてある焼結温 度で急激に密度が高くなっており，その温度以上では相対密 度が100\%に近い值を示した.そこで, 各炭素量において相対 密度が $98 \%$ に到達した温度を今後 $\mathrm{Ts}$ と呼ぶ. 図中に, 各炭素 量におけるTsを矢印で示してある.この温度Tsは, 炭素量が 多くなれば低くなっており，M2高速度工具鋼における M2炭素擬 2 元系状態図の固相線 ${ }^{8}$ より 5〜 10K 高い温度であっ た.このTsの温度で急激に焼結密度が高くなったのは，焼結 時に液相が発生したためである。

圧粉体の焼結による寸法収縮率は, 高速度工具鋼ではTs以 上の温度の条件において約 $8 \%$ と大きな值を示した.一方低合 金鋼では，温度による焼結密度への影響はほとんどなく，圧 粉体の焼結による寸法収縮率も約 $0.5 \%$ と小さかった.すなわ ち, Ts以上の温度の条件では, 高速度工具鋼と低合金鋼とで 焼結時の寸法収縮量に大きな差が生じていた。

3.2 焼結接合材の組織

Fig.4に，炭素量 0.94 mass\%，焼結温度 $1493 \mathrm{~K}$ の試料と，炭 素量 1.14 mass\%，焼結温度 $1513 \mathrm{~K}$ の試料，および炭素量 1.34 mass\%，焼結温度 $1513 \mathrm{~K}$ の試料の接合界面組織を示す.これ らの組織観察は, 研磨仕上げした試料を塩化第二鉄溶液で腐

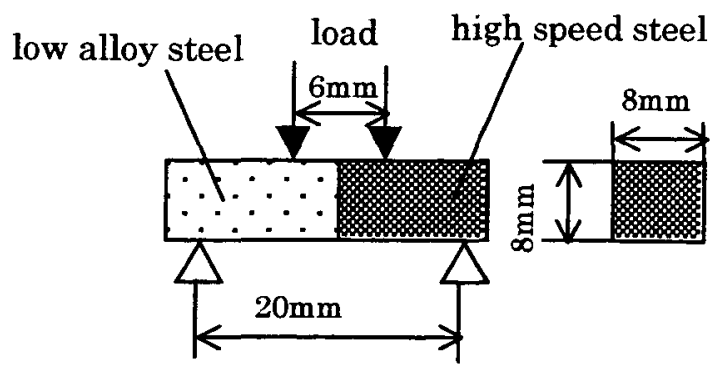

Fig.2 Method of four points bending test for bonded specimen.

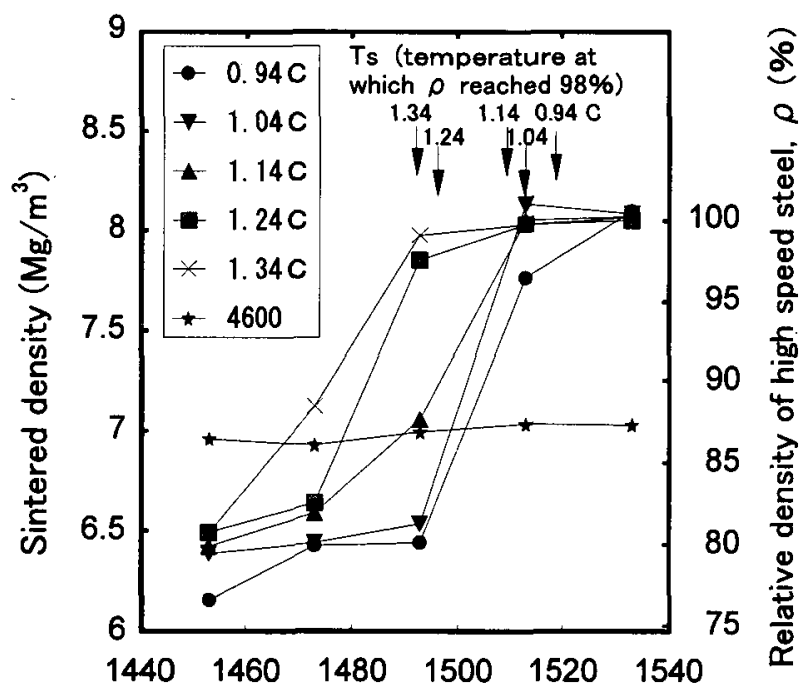

Sintering temperature (K)

Fig.3 Relationship between sintering temperature and sintered density. 


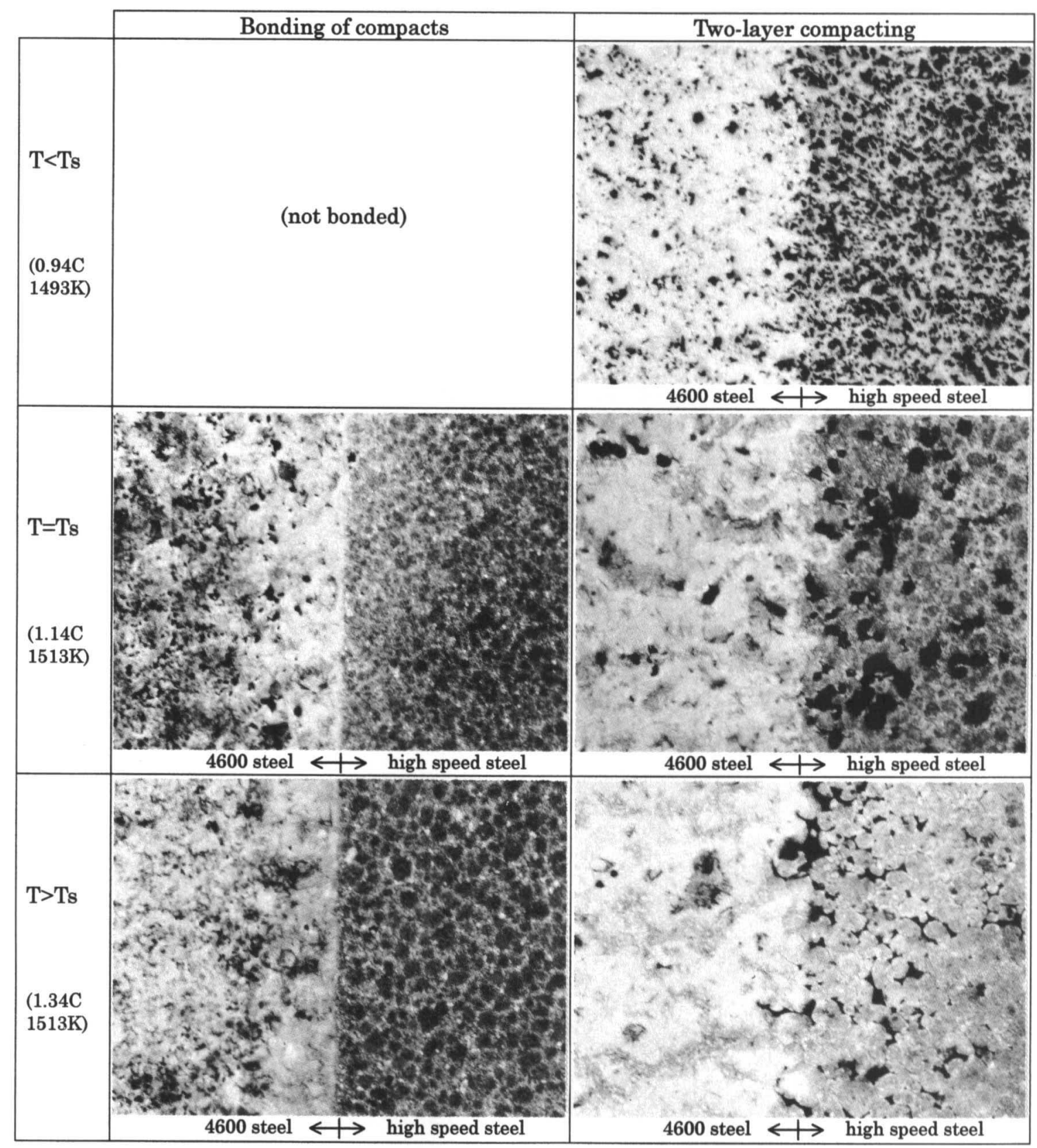

$\underline{200 \mu \mathrm{m}}$

Fig.4 Microstructure of bonding interface for specimens of 0.94 mass $\%$ sintered at $1493 \mathrm{~K}, 1.14$ mass $\%$ sintered at $1513 \mathrm{~K}$, and $1.34 \mathrm{mass} \%$ sintered at $1513 \mathrm{~K}$.

食させて行った.この組織において, 右側が高速度工具鋼, 左 側か低合金鋼である.組織中で黒く見える部分はポアである. まず圧粉体同志接合について見ると, 焼結温度がTsより低 い条件(炭素量0.94 mass\%, 焼結温度1493K)では接合しなかっ た.一方 Tsの条件 $(1.14$ mass\%, $1513 \mathrm{~K})$ では, 良好な接合組織 が得られ，高速度工具鋼のポアもほとんど無くなっていた。 さらに, 低合金鋼側の接合部近傍に白色に観察される抎散層 も認められた. また, 焼結温度がTsより高い条件(1.34 mass\%, $1513 \mathrm{~K})$ では, 高速度工具鋼の結晶粒が粗大化していることが わかる.
次に2層成形接合について見ると, Ts より温度の低い条件 $(0.94$ mass \%, 1493 K) では, 高速度工具鋼の焼結密度が低いた めポアが多く観察されるものの, 接合界面は良好な組織が得 られた. 一方 Tsの条件 $(1.14$ mass\%, 1513 K) では, 高速度工具 鋼の密度が上がっている条件にもかかわらず, 高速度工具鋼 の接合部近傍で比較的大きなポアが観察された.このポアは, 接合面から離れると除々に少なくなり, 約 $2 \sim 3 \mathrm{~mm}$ 以上離れ ると観察されなかった.したがってこのポアは，接合部付近 の高速度工具鋼の焼結収縮が低合金鋼により拘束されて絰密 化が阻害されたために生じたもの ${ }^{9}$ と考えられる.一方, 焼 
結温度がTsより高くなると，高速度工具鋼側の接合部近傍で 不規則形状をしたポアが観察された.このポアは，接合面か ら約 $0.8 \mathrm{~mm}$ 以上離れると観察されなかった.また, 焼結温度
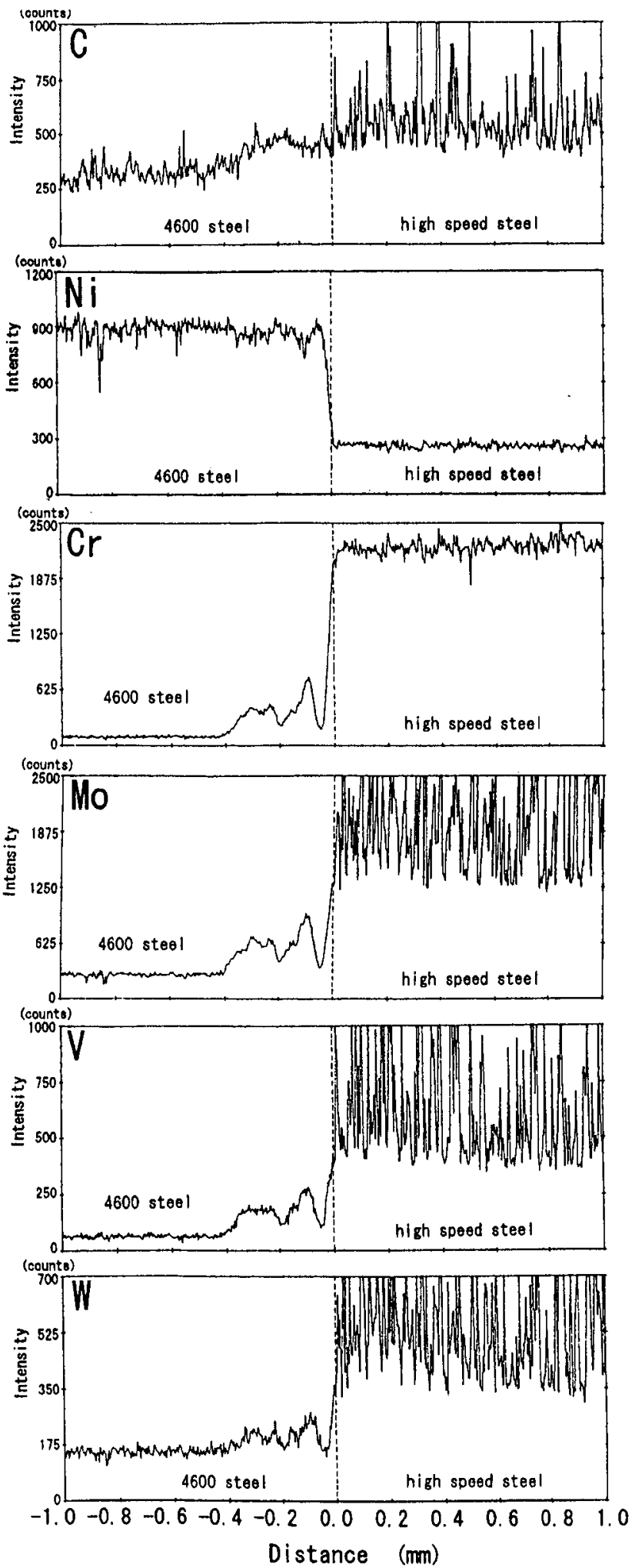

Fig.5 EPMA of alloying elements at bonding interface (Specimen: bonded of two green compacts, carbon content 1.14 mass\%, sintering temperature $1513 \mathrm{~K}$ ).
が $1533 \mathrm{~K}$ と高い条件の圧粉体同志接合材にも，このようなポ アが観察された。したがってこのポアは，高速度工具鋼で発 生した液相が低合金鋼に拡散したために生じた流出孔と考え られる.なお, 2層成形接合の接合界面を圧粉体同志接合と比 較すると，圧粉体同志接合では接合界面の境が直線的である のに対し，2層成形接合では接合界面が凹凸状になっており， 成形時に低合金鋼と高速度工具鋼の粉末が絡み合って焼結時 に接合されたことがわかる.

Fig.5に，接合界面におけるEPMA元素分析の結果の例を示 す.この試料は，炭索量 $1.14 \mathrm{mass} \%$ ，焼結温度 $1513 \mathrm{~K}$ の条件 の圧粉体同志接合材である.高速度工具鋼の合金元素である $\mathrm{C}, \mathrm{Cr}, \mathrm{Mo}, \mathrm{V}, \mathrm{w}$ が低合金鋼側に拡散していることがわかる. この拡散層の厚みは $0.35 \mathrm{~mm}$ と見積もられ，結晶粒が粗大化 して光学顕微鏡で白っほく観察された層の厚みと一致してい た ${ }^{10)}$.また，接合部近傍においてビッカース硬さ試験により 硬さ分布を調查したところ，拡散層の硬さは，高速度工具鋼 のマトリックス硬さHV750 と低合金鋼のマトリックス硬さ HV180の間の值を示し，接合界面から離れるにしたがって 除々に低下していた.そこで，このEPMAおよび光学顕微鏡 による組織観察により拡散層の厚みを求め, それを焼結温度 (絶対温度)の逆数に対してプロットしたものをFig.6に示す. この図の試験片は，炭素量 1.04 mass\%のものである. 圧粉体 同志接合において，接合しなかったTsより低い温度の条件で は，拡散層は認められなかった。一方，2層成形接合では Ts 以下の温度でも数 $10 \mu \mathrm{m}$ の抎散層が観察された．また，Ts 以 上の温度になると, 液相が発生するため圧粉体同志接合でも 拡散層が認められるようになり,とくに2層成形接合では数 $\mathrm{mm}$ の厚みに及ぶ拡散層が生成していた.

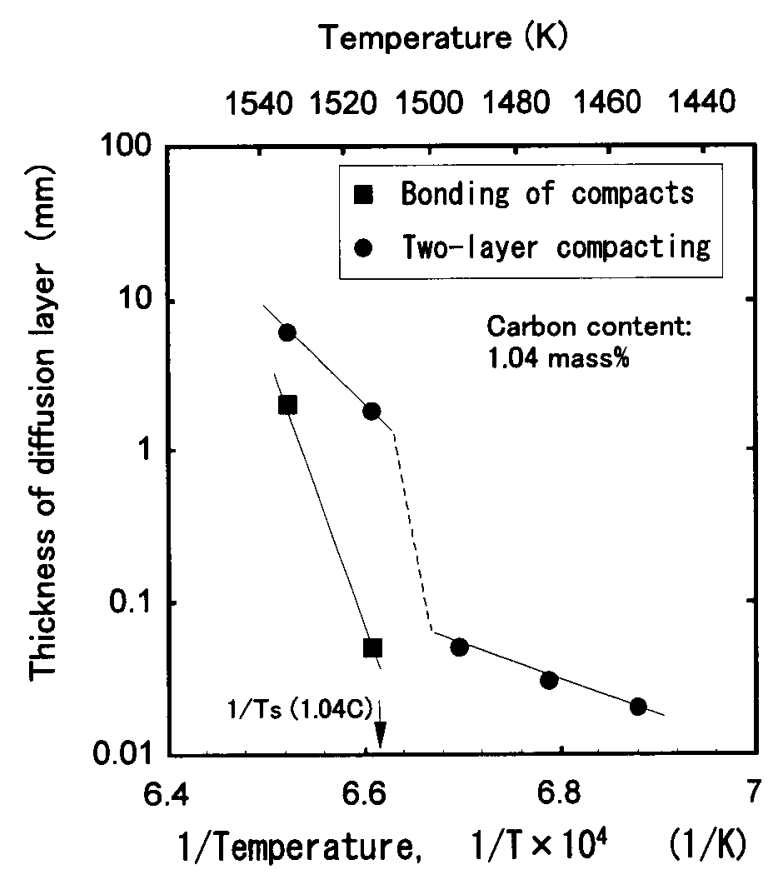

Fig.6 Relationship between thickness of diffusion layer and sintering temperature. 


\section{3 接合材の 4 点曲げ強度}

Fig.7に, 接合材ではない単味焼結材の 4 点曲げ強度の結果を 示す. 高速度工具鋼の焼結材では, 焼結温度が上昇するにした がって曲げ強度が増加し, 各炭素量において相対密度が $98 \%$ に到達した焼結温度 Ts 付近で最大の強度 $(700 \sim 1100 \mathrm{MPa})$ を 示した. しかし, 焼結温度がTsより高くなると曲げ強度は低 下した.これは, 焼結温度がTs より高くなると, 結晶粒が粗 大化するためである7 . なお, 焼結温度 $1513 \mathrm{~K}$ における炭素 量1.34 mass\%と, 焼結温度1533 Kにおける炭素量が1.14 mass\% 以上の条件のデータが無いのは, この条件では液相量が多す ぎるために焼結材が変形して曲げ試験ができなかったためで ある・

次に, 圧粉体同志接合材の 4 点曲げ強度を Fig.8に示す. 液 相の発生しないTsより低い焼結温度では全く接合せず, 曲げ 強度は 0 であった. しかしながら，焼結温度が上昇するにし たがっていずれの炭素量においても曲げ強度が増加し, Tsよ り約 $20 \mathrm{~K}$ 高い焼結温度で最大曲げ強度 $(500 \mathrm{MPa})$ を示した.さ らに焼結温度が高くなると曲げ強度は低下した。この曲げ強 度の変化を破断位置と関連付けて検討するため,4点曲げ破断 試験片の破断部の組織を観察した.

Fig.9に, 圧粉体同志接合材の 4 点曲げ破断試験片における 破断部の断面組織写真を示す. Fig.9(a)は, Tsの条件の試験片 $(1.24$ mass\%, $1493 \mathrm{~K})$ で，高速度工具鋼の相対密度は $98 \% に$ 到 達しているが曲げ強度は低かったものである．この試験片で は接合部で破断しており，液相量が少なかったために接合界 面の強度は低かったと考えられる.一方Fig.9 (b)は, 曲げ強度 が最も高かった試験片 $(1.24$ mass\%, 1513 K) で，Tsより温度が 高くなって液相量が増えると接合部の強度は増加し, 組織が 粗大化した高速度工具鋼で破断したことがわかる．以上のこ

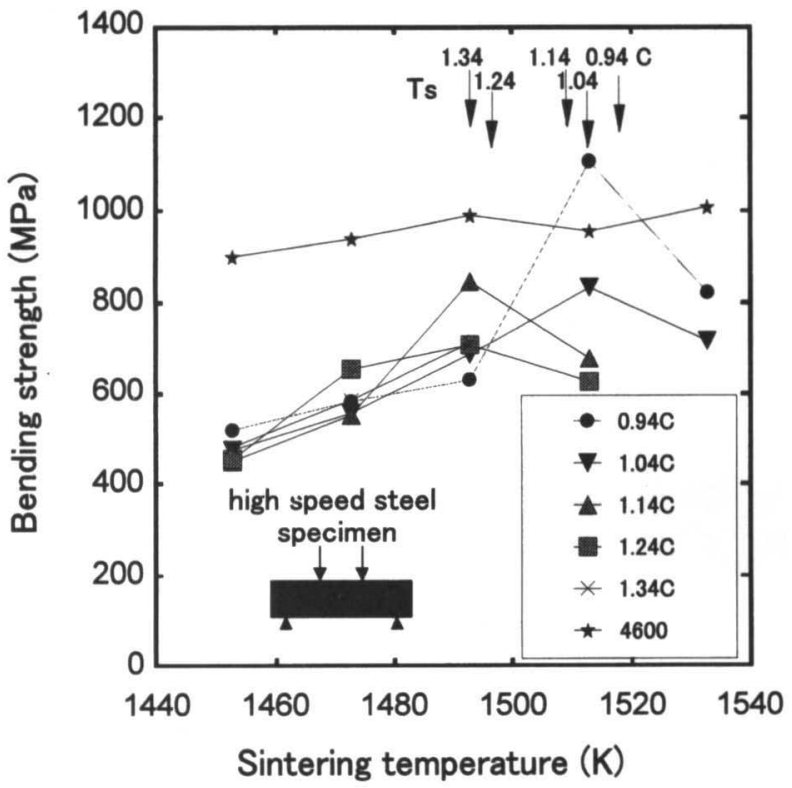

Fig.7 Effect of sintering temperature and carbon content on four points bending strength for sintered high speed steel specimen.
とより, 接合材の強度の観点からすると, 圧粉体同志接合で はある程度の液相量が必要で, Ts より $20 \mathrm{~K}$ 高い焼結温度が適 しているといえる.

次に, Fig.10に 2 層成形接合材の 4 点曲げ強度を示す. 多少 ばらつきはあるものの焼結温度,炭素量に関係なく200〜 450MPa

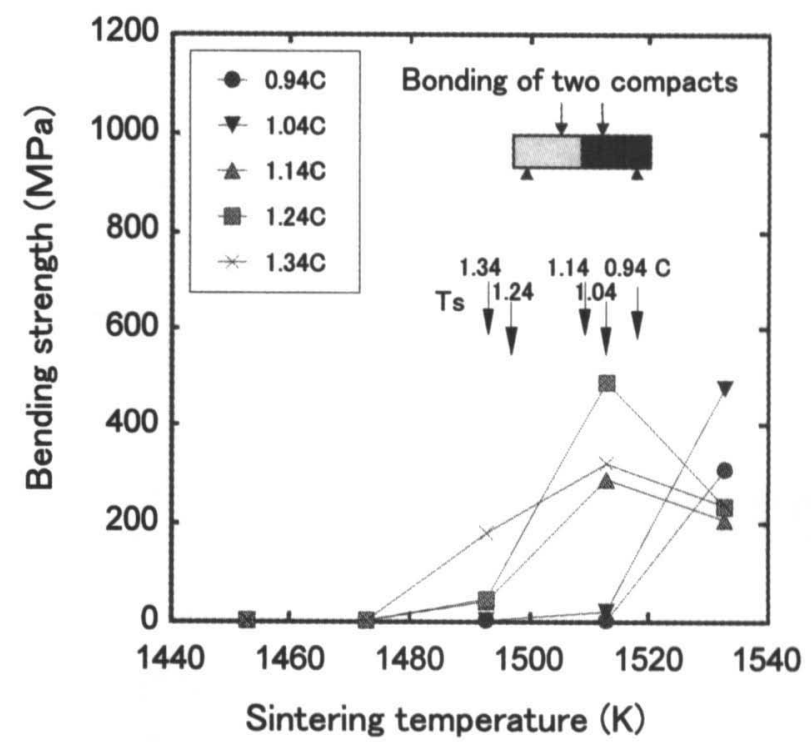

Fig.8 Effect of sintering temperature and carbon content on four points bending strength for bonded specimen of two green compacts.
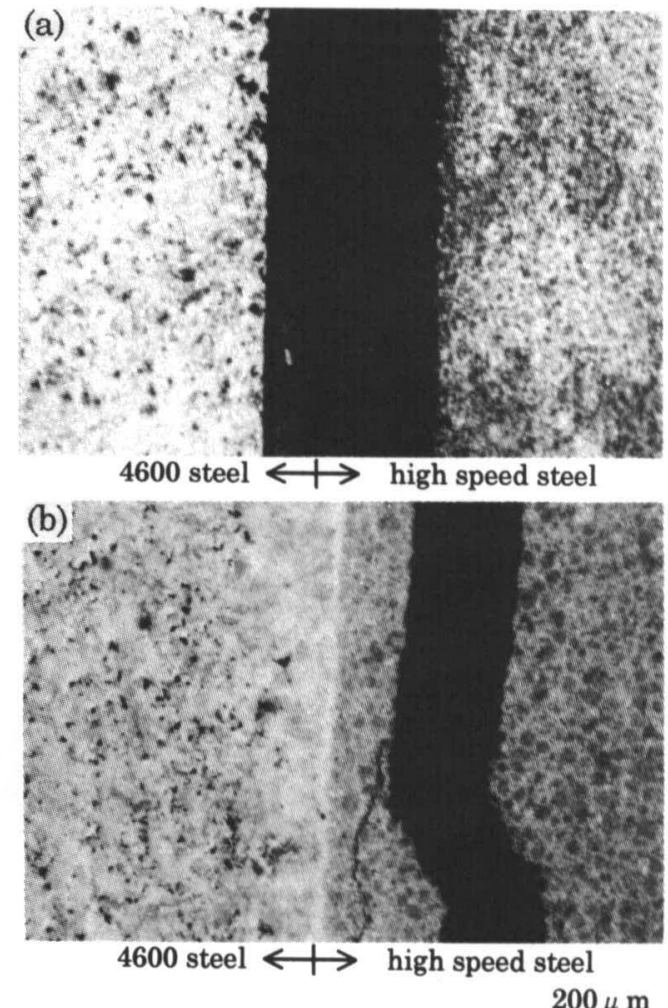

Fig.9 Microstructure of section of specimen ruptured by four-point bending test (Specimen: bonded of two green compacts, (a) $1.24 \mathrm{C}, 1493 \mathrm{~K}$, (b) $1.24 \mathrm{C}, 1513 \mathrm{~K}$ ). 


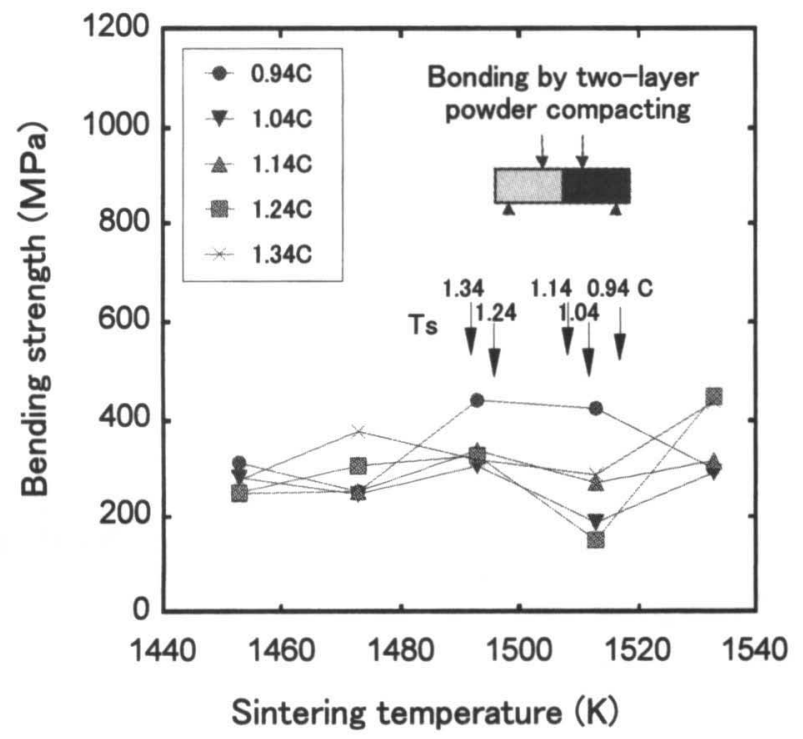

Fig.10 Effect of sintering temperature and carbon content on four points bending strength for specimen bonded by two-layer powder compacting.
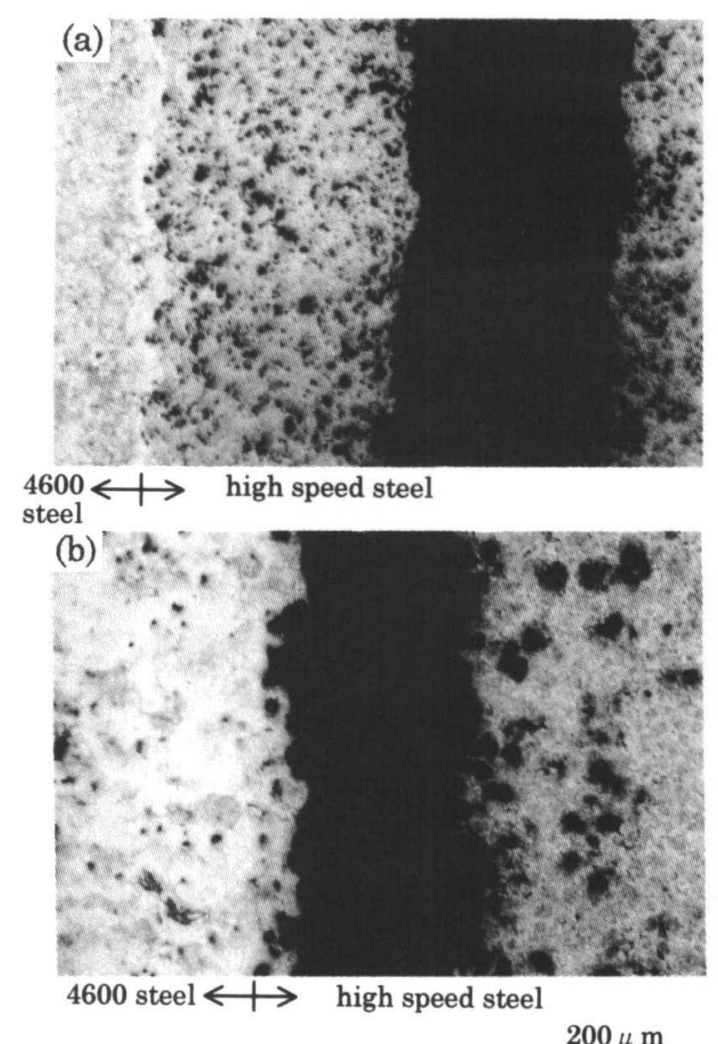

Fig.11 Microstructure of section of specimen ruptured by four-point bending test (Specimen: bonded by two-layer compacting, (a) $0.94 \mathrm{C}, 1493 \mathrm{~K}$, (b) $1.04 \mathrm{C}, 1513 \mathrm{~K}$ ).

の範囲の值を示し, その值も Fig.7 の単味焼結材より低かっ た. すなわち, 液相の発生しないTsより低い焼結温度でもあ る程度の曲げ強度を示すが, 焼結温度が Ts 以上になって高速

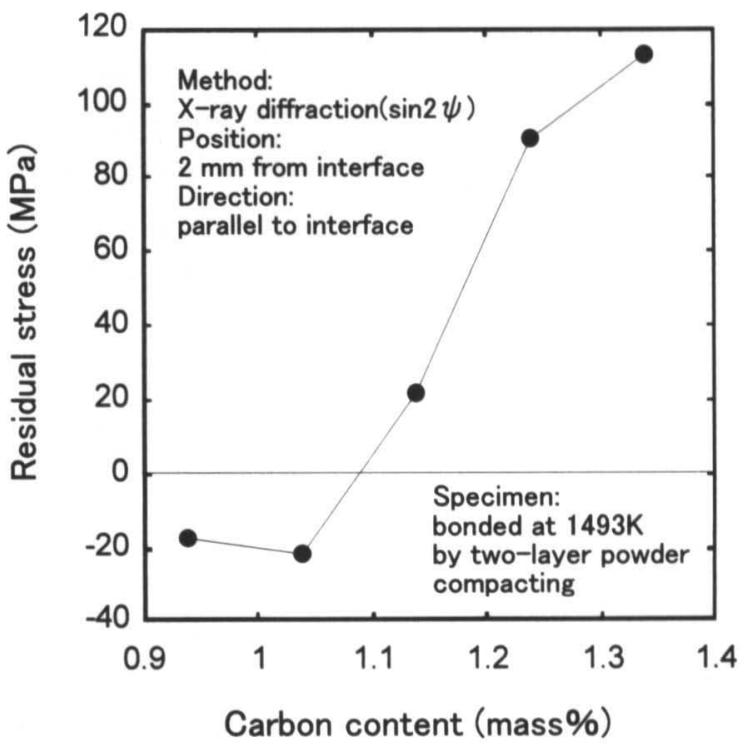

Fig.12 Relationship between carbon content and residual stress of the specimen bonded at $1493 \mathrm{~K}$ by two-layer powder compacting.

度工具鋼の密度が高くなっても, 曲げ強度の変化に増加傾向 は認められなかった. また, 曲げ強度の最大の值も, 圧粉体 同志接合のそれと比べると若干低かった.

Fig.11は, 2 層成形接合材の 4 点曲げ破断部の断面組織写真 である. Fig.11(a)は, 焼結温度が Tsより低い条件の試験片 $(0.94$ mass\%, 1493 K)で, 密度の上がっていない高速度工具鋼で 破断していたことがわかる. また Fig.11(b)は, 高速度工具鋼 の相対密度が 98\%に到達した Ts の条件の試験片 (1.04 mass\%, $1513 \mathrm{~K})$ で, 高速度工具鋼の接合部近傍で焼結収縮の阻害が原 因で発生していたポアに沿うように破断していた. なお，焼 結温度が Tsより高い条件の試験片では, 接合部近傍で観察さ れた流出孔と思われるポアに沿って破断していた.したがっ て,これらのポアが, Ts 以上に焼結温度が高い条件でも 2 層 成形接合材の曲げ強度が上がらなかった理由の一つと考えら れる.

Fig.12 は, 焼結温度 $1493 \mathrm{~K}$ における 2 層成形接合材の高速 度工具鋼の炭素量に伴う残留応力の変化を示したものである. この残留応力は, 接合面から $2 \mathrm{~mm}$ 離れた高速度工具鋼側で測 定し, 応力の測定方向は接合面に平行である.この図より, 炭 素量が多い試験片では引張残留応力が発生していることがわ かる.この焼結温度では, 炭素量 1.24 mass\% 以上で高速度工 具鋼の相対密度が98\% 以上になっており, 高速度工具鋼の焼 結時の寸法収縮量が低合金鋼と比べて大きくなっているため に, 引張残留応力が発生したと考えられる. したがって,こ の引張残留応力も高速度工具鋼の密度が上がっている 2 層成 形接合材で曲げ強度が低かった原因と考えられる。

以上のことから, 2 層成形接合材は, 高速度工具鋼側のポア や接合材の引張残留応力が原因で, 焼結温度, 炭素量に関係 なく曲げ強度がほぼ一定の低い值を示したと考えられる。 


$$
4 \text { ま と め }
$$

本研究では，低合金鋼と高速度工具鋼の焼結接合として圧 粉体同志接合と 2 層成形接合に着目し，高速度工具鋼の炭素 量を $0.94 \mathrm{mass} \%$ から 1.34 mass\%，焼結温度を $1453 \mathrm{~K}$ から $1533 \mathrm{~K}$

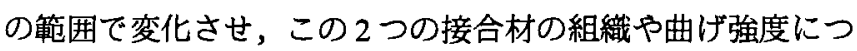
いて調查した．得られた結論は次の通りである.

(1) 圧粉体同志接合では,液相の発生しない条件では全く接合 しないが，高速度工具鋼の相対密度が $98 \%$ に到達した温 度 Ts 以上の焼結温度で，良好な接合組織が得られた。一 方2層成形接合では，Tsの条件では焼結収縮が阻害された ためにできたと思われるポアが高速度工具鋼の接合部近傍 で観察され，さらにTsより高い焼結温度では流出孔と考 えられるポアが接合部近傍で観察された。

(2) 圧粉体同志接合は, 高速度工具鋼の単味焼結材の最大曲げ 強度を示した温度 (Ts)より $20 \mathrm{~K}$ 高い焼結温度で最大の曲 げ強度を示し，接合にはある程度の液相量が必要であるこ とがわかった。

(3) 2 層成形接合の曲げ強度は, 焼結温度, 炭素量に関係なく ほぼ一定の值を示し，その最大值も圧粉体同志接合のそ れと比べると若干低かった。これは，高速度工具鋼の接 合部近傍のポアや接合材の引張残留応力が原因と考えら れた。

\section{文献}

1) 早坂忠郎, 浅香一夫: "鉄系粉末冶金部品の接合法", 材料 科学, 21(1984)160-166.

2) 間山治, 山田晃二: "焼結機械部品の接合技術について", 素 形材, 27(1986)11-15.

3) 高橋堅太郎, 平岡武, 中村義勝, 川村治, 清水一大: " 而摩 耗性焼結合金 PE1", 日本金属学会会報, 23(1984)422-424.

4) 川村治: "焼結接合技術 $\sigma$ 展開 ", 内燃機関, 26(1987)58-63.

5) I.Gotman and E.Y.Gutmanas: "Joining of P/M T15 high speed steel with 4640 steel by cold sintering", Powder Metall. Int., 19 (1987)11-14.

6) C.S.Wright and B.Ogel: "Supersolidus sintering of high speed sieels", Powder Metall., 36(1993)213-219.

7) 鎌田善仁, 徳山幸夫: "水アトマイズ工具鋼粉末の特性と用 途", 素形材, 26(1985)7-13.

8) R.H.Barkalow, R.W.Kraft and J.I.Goldstein: "Solidification of M2 high speed steel", Metall. Trans., 3(1972)919-926.

9) 松本修次, 野村浩, 松原秀影, 清水正義: "液相焼結の MC シミュレーションー基板拘束の影響—",粉体粉末治金協会 平成 13 年度秋季大会概要集, (2001) 240 .

10) I.Gotman and E.Y.Gutmanas: "Diffusion and microstructual changes at $1200^{\circ} \mathrm{C}$ in cold-sintered T15-4640 joints", J. Mat. Sci. Let., 6(1987)1303-1306. 